\title{
Hoe relevant is nadenke oor die hemel en hel vandag?
}

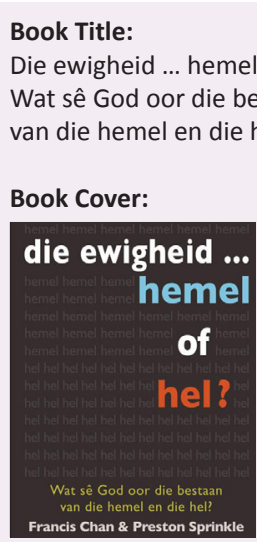

Authors:

Francis Chan

Preston Sprinkle

ISSN:

978-1-4316-0336-7

Publisher:

Vereeniging, Christelike Uitgewersmaatskappy, 2013 R89.95*

*Book price at time of review

$\square$

Review title:

Hoe relevant is nadenke oor die hemel en hel vandag?

Reviewer:

Nicolaas P. Heystek ${ }^{1}$

\section{Affiliation:}

${ }^{1}$ Gereformeerde Kerk

Wapadrant, South Africa

Email:

klasie@gkwapadrant.co.za

Postal address:

PO Box 38229, Garsfontein-

Oos 0060, South Africa

How to cite this book review: Heystek, N.P., 2013, 'Hoe relevant is nadenke oor die hemel en hel vandag?', In die Skriflig/In Luce Verbi 47(1), Art. \#1723, 1 page. http:// dx.doi.org/10.4102/ids. v47i1.1723

Read online:

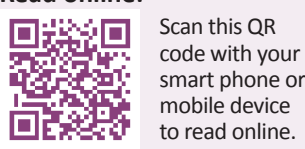

Hierdie boek is die Afrikaanse vertaling deur Esta Grobler van die oorspronklike Engelse uitgawe, Erasing hell (2011). Die oorspronklike teks is vóór publikasie aan verskeie akademici vir skaafwerk en aanvulling voorgelê waardeur die betroubaarheid van die inhoud verhoog is.

Die inisiële skrywer Francis Chan, benader die kwessie van die hel vanuit 'n pastorale hoek. Hy vertel van die slegste dag in sy lewe, naamlik die sterfdag van sy ouma:

Volgens wat ek in die Bybel gelees het, het sy op die drumpel van 'n ewigheid van nimmereindigende smart gestaan. Dit het gevoel ek gaan van my kop af raak. (bl. 9)

Vrae oor die werklikheid van die hel en veral die sin daarvan het hom aangegryp. Hy het biddend (bl. 10-13) begin antwoorde soek: Is daar 'n plek soos die hel in die skepping? Wat sê die Ou Testament oor die hel? Wat was Jesus en sy volgelinge se siening? Indien die hel wel bestaan, wat is die bedoeling daarvan?

Die boek is logies uitgebou. Die eerste hoofstuk handel oor die kwessie van universele verlossing. Hoe moet die almal-tekse verstaan word, byvoorbeeld: '[S]o sal almal in Christus lewend gemaak word' (1 Kor 15:22; vgl. ook 2 Kor 5:19; Kol 1:19-20; 1 Tim 2:4)? Universalisme soos dit deur verskeie teoloë voorgestaan word, word afgewys (bl. 19-20). Die betrokke (probleem)tekste word in hulle konteks verklaar (bl. 20-29). Die begrippe God se morele wil (anti-sonde) en soewereine wil (Godsregering) is 'n goeie verklaringspoging, maar dit klaar ongelukkig nie die kernvrae oor die voorsienigheid van God op nie (bl. 24-26).

In hoofstuk twee (bl. 33-44) word die Ou Testament (veral Dan 12 en Eseg 32:17-32) van nader bekyk, asook die standpunte van Joodse skrywers tussen 200 v.C. tot 100 n.C. (veral Henog 1 en 2, Wysheid, Makkabeërs en Barug). Hierdie gedeelte is belangrik, aangesien dit die konteks vorm vir die verstaan van die uitsprake van Christus en sy volgelinge. Belangrike inligting word hier verskaf.

Hoofstuk drie handel oor Jesus se uitsprake oor die hel (bl. 47-62) en hoofstuk vier oor die leer van sy volgelinge (bl. 63-74) - veral dié van Paulus, Petrus, Judas en Johannes in Openbaring. Die eindsom hiervan is die volgende: Daar is 'n werklike toestand (bl. 71) of 'n plek (bl. 109) wat as die hel bestaan. Dit word met verskillende terme en uitdrukkings beskryf (bl. 47-109).

In hoofstukke vyf, ses en sewe word na die pastorale konsekwensies van die bevindings gekyk. Hoe beïnvloed die wete van 'n oordeel ná hierdie lewe my eie lewe (hoofstuk 5, 7) en veral my verhouding met God (hoofstuk 6)? Hier is Chan as die pastor en prediker aan die woord. Voorbeelde word gegee hoe om hierdie moeilike onderwerp as waarskuwing te verkondig.

In 'n Bylae word sewe vrae wat dikwels gevra word, op die man af beantwoord (bl. 107-115). Die inhoud van die boek word laastens deur 'n bibliografie en verklarings ondersteun (bl. 117-134).

Hierdie boek bied 'n breë agtergrond, in 'n populêre skryfstyl, vir elkeen wat meer oor die onderwerp wil weet. Die feit van Christus se wederkoms en eindoordeel plaas elke mens voor 'n beslissende keuse (Joh 9:39). As antwoord op die boek en in 'n mens se nadenke oor die hemel en die hel (die hoofaksent van boek lê by die hel), behoort 'n paar opmerkings gemaak te word. Allereers kan niemand oor 'n ander se eindbestemming oordeel nie, dit is God se saak (bl. 9; Gen 18:25). Ons opdrag is om mense te waarsku, maar God is die enigste Regter. Tweedens word mense nie salig deur die hel te verkondig nie, maar wel deur die verkondiging van Jesus Christus. Die tema van die evangelie is God se genade in Christus, deur die Gees (2 Kor 5:11-21). Wie dit afwys, wys die (ewige) lewe af en bly in die dood. Derdens is dit baie moeilik om 'n bepaalde verstaan van die hel op te eis. In die Christelike leer is verskillende moontlikhede aangebied (vgl. Van den Brink, G. \& Van der Kooi, C., 2013, 'Christelijke Dogmatiek', bl. 668-673). Die hoofsaak is dat ons sonder geloof in Christus se versoening en die werklikheid van ons herskepping, in die hel van die sondedood en vernietiging vasgevang bly. 